Article

\title{
Place, Capital Flows and Property Regimes: The Elites' Former Houses in Beijing's South Luogu Lane
}

\section{Zhifen Cheng ${ }^{1,2}$, Shangyi Zhou ${ }^{1, *}$ and Stephen Young ${ }^{3}$}

1 School of Geography, Beijing Normal University, Beijing 100875, China;

E-Mail: zhifencheng2004@163.com

2 Institute of Beijing Studies, Beijing Union University, Beijing 100101, China

3 Department of Geography, University of Wisconsin-Madison, 550 North Park Street, Madison, WI 53706, USA; E-Mail:sjyoung3@wisc.edu

* Author to whom correspondence should be addressed; E-Mail: shangyizhou@bnu.edu.cn; Tel.: +86-10-6224-7385.

Academic Editor: Marc A. Rosen

Received: 21 August 2014 / Accepted: 22 December 2014 / Published: 31 December 2014

\begin{abstract}
Place is seen as a process whereby social and cultural forms are reproduced. This process is closely linked to capital flows, which are, in turn, shaped by changing property regimes. However, relatively little attention has been paid to the relationship between property regimes, capital flows and place-making. The goal of this paper is to highlight the role of changing property regimes in the production of place. Our research area is South Luogu Lane (SLL) in Central Beijing. We take elites' former houses in SLL as the main unit of analysis in this study. From studying this changing landscape, we draw four main conclusions. First, the location of SSL was critical in enabling it to emerge as a high-status residential community near the imperial city. Second, historical patterns of capital accumulation influenced subsequent rounds of private investment into particular areas of SLL. Third, as laws relating to the ownership of land and real estate changed fundamentally in the early 1950s and again in the 1980s, the target and intensity of capital flows into housing in SLL changed too. Fourth, these changes in capital flow are linked to ongoing changes in the place image of SLL.
\end{abstract}

Keywords: place-making; capital flows; property regimes; elites' former houses; Beijing 


\section{Introduction}

The old city of Beijing contains a number of designated "historic preservation districts". This phenomenon can be seen in many cities around the world. For example, Power writes that city centers in the UK are "rich in cultural magnets, remarkable buildings, attractive streets and public spaces that can be economic as well as social assets" [1] (p. 733). Razzu describes central Accra, the capital of Ghana, as a mosaic of historical buildings of various uses and natures, including private houses, palaces and monuments [2] (p. 400).

As numerous scholars have argued, historical places are really distillations of much broader social and spatial processes [3]. Massey has persuasively made the case that what gives any place its specificity "is not some long internalized history but the fact that it is constructed out of a particular constellation of social relations, meeting and weaving together at a particular locus" [4] (p. 154). Yet, the ways in which this weaving takes place is far from uniform. In some instances, scholars emphasize how successive cycles of capital accumulation deposit new layers in the urban landscape [5-7]. Yet, there are also important cultural and political contingencies that produce different outcomes across time and space [8,9].

This paper adds nuance to these debates through a case study of South Luogu Lane (SLL), a historic preservation area in central Beijing. Having first emerged in the 13th century, it has become one of the most well-known districts of the city and, in 2009, was named by Time (a weekly news magazine) as one of the top 25 Asian tourism destinations where one could experience "local customs". SLL provides us with an opportunity to study transformations in the production of place over the longue durée. In doing so, we argue that it is important to pay particular attention to changing property regimes that, in turn, have profoundly influenced the geography of capital flows into SLL over time.

In the following section, we situate our work in relation to wider debates about property regimes, capitalism and place-making. We then introduce the site that is the focus of our analysis. In Sections 4-7, we examine the transformation of SLL over four historical periods. In the conclusion, we recapitulate our major findings and reflect on how our case study nuances broader arguments about the production of place.

\section{Layered Landscapes}

Place-making is a core topic in cultural geography. Place is seen as a process whereby social and cultural forms are reproduced and reworked by multiple, intersecting processes. This includes economic relations. Indeed, a historic preservation district's features are, in large part, the result of capital accumulating in different ways over different periods of time. Harvey argued: "Places arise, constituted as fixed capital embedded in the land and configurations of organized social relations, institutions, etc. on the land" [10]. Harvey has also described how property laws and financial instruments are linked to the destruction of certain forms of capital in the built landscape, paving the way for new waves of reinvestment and rebuilding $[11,12]$.

Scholars have also suggested that places must be seen as constituted out of spatialized social and economic relations that extend well beyond their national boundaries [13,14]. Place-making is therefore an inherently networked process, constituted by the socio-spatial relationships that link individuals together through a common place-frame [15]. Massey has argued that as the global and regional 
distribution of economic activity transformed, new layers of materiality are overlain on the pattern produced in previous eras [16,17]. The combination of successive layers gives rise to a new form and spatial distribution of inequality in the conditions of production, which then form the basis for future rounds of investment. Places must be understood as flexible entities, always open and in-the-making [18,19]. The "local" culture and landscape of any given place is the complex result of the combination of different layers and linkages that are conditioned by wider, national or international, spatial divisions of labor [7]. Interdependence and uniqueness must therefore be seen as "two sides of the same coin" [20].

Yet, it remains unclear why processes of place-making may diverge across time and space. Warde states that "the notion of layers raises the issue of whether the mechanisms which generate one layer are the same as those which generated previous layers. Should we expect different layers to be formed by different forces, or simply by the same forces successively over time?" [8] (p. 198). As Warde suggests, we need to better understand when, and for what reasons, one layering process subsides and another emerges [8]. There has been relatively little work examining these processes, particularly outside European and North American cities [2,3]. Our paper applies this analytical framework into SLL in the old city of Beijing. The area offers a compelling case study because of its long history and its changing cultural and strategic significance to different political regimes. We show how the process of building, repairing, and purchasing and allocating the houses in SLL has been shaped by changing property regimes. By identifying key driving factors in different eras, we are able to nuance some of the more general claims made by geographers about the production of place.

\section{Beijing's South Luogu Lane}

SLL was originally built in 1267 when the capital city of the Yuan Dynasty was constructed. The government was based in the imperial city, which comprised the core of the city. The Imperial Ancestral Temple was to the east while the Altar of Land and Grain lay in the west. The major market area was to the north. SLL was close to the major market area and was located in the central area of the city [21]. SLL was at the boundary of the Zhaohui community and the Jinggong community [22]. In the first half of the Ming Dynasty, the north wall and the south wall of Beijing City moved to the south (the north wall about $2.5 \mathrm{~km}$ to the south, the south wall about $1 \mathrm{~km}$ to the south), thereby decreasing the city's land size. SLL was now located in the northeast corner of the city. In the second half of the Ming Dynasty, a new outer city was built in Beijing that was based on the inner city. The city was then divided into 28 communities and SLL was part of the Zhaohuijinggong community. It was close to the imperial city during the Yuan, Ming and Qing Dynasties (see Figure 1). From the Qing Dynasty until the creation of the People's Republic of China (PRC), SLL was densely occupied. The relative location of SLL in the old city of Beijing is shown in Figure 1.

At present, the northern boundary of SLL is along Gulou E. Street, the southern boundary is Dianmen E. Street, the western boundary is Dianmenwai Street and the eastern boundary is Jiaodaokou S. Street. The streets all belonged to one of the main thoroughfares in the capital city of the Yuan Dynasty. SLL's eastern part and western part are separately comprised of eight Hutongs (or "lanes"). The area of SLL and the Hutongs in it are shown in Figure 2. 


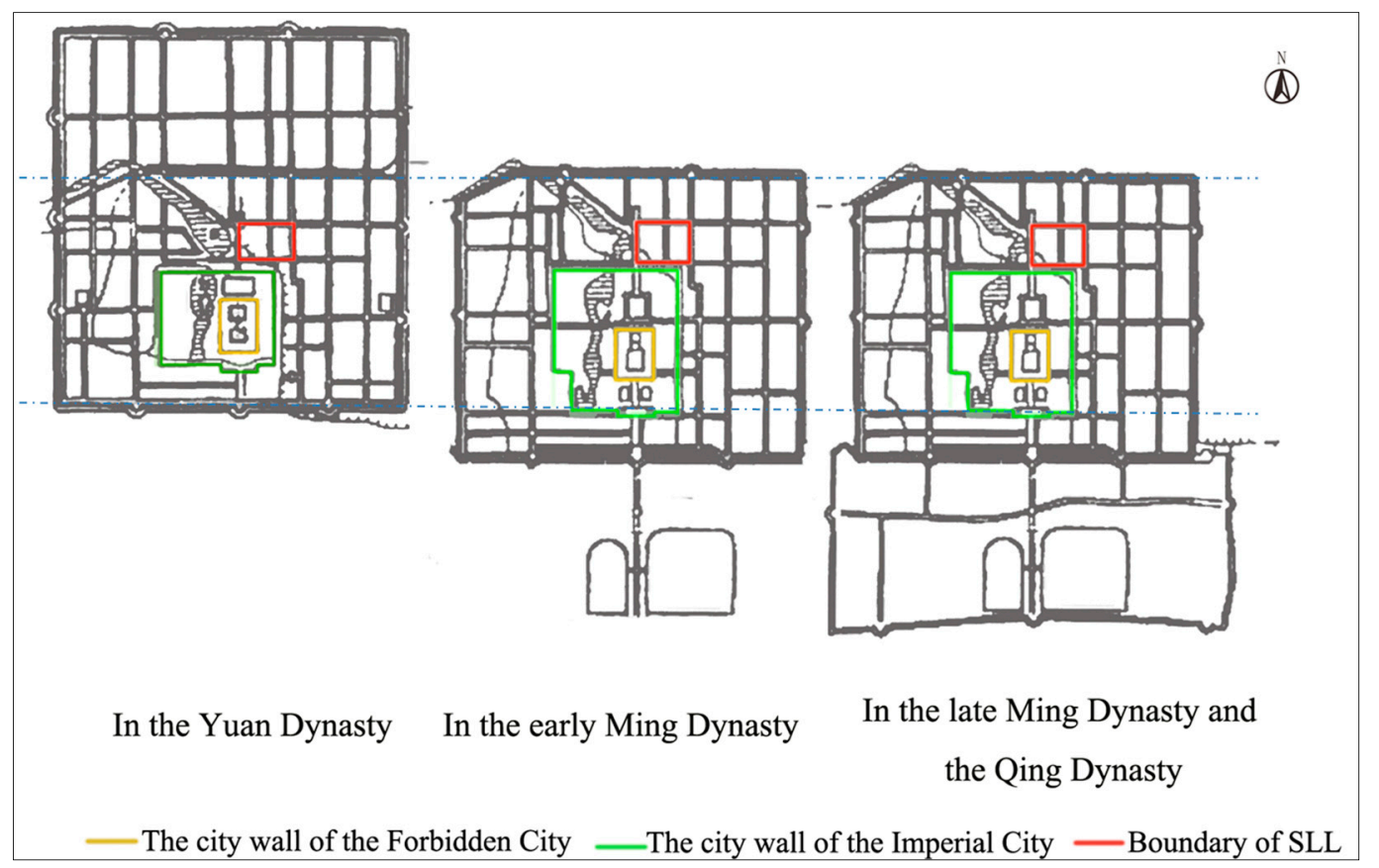

Figure 1. The relative location of SLL in the old city of Beijing.

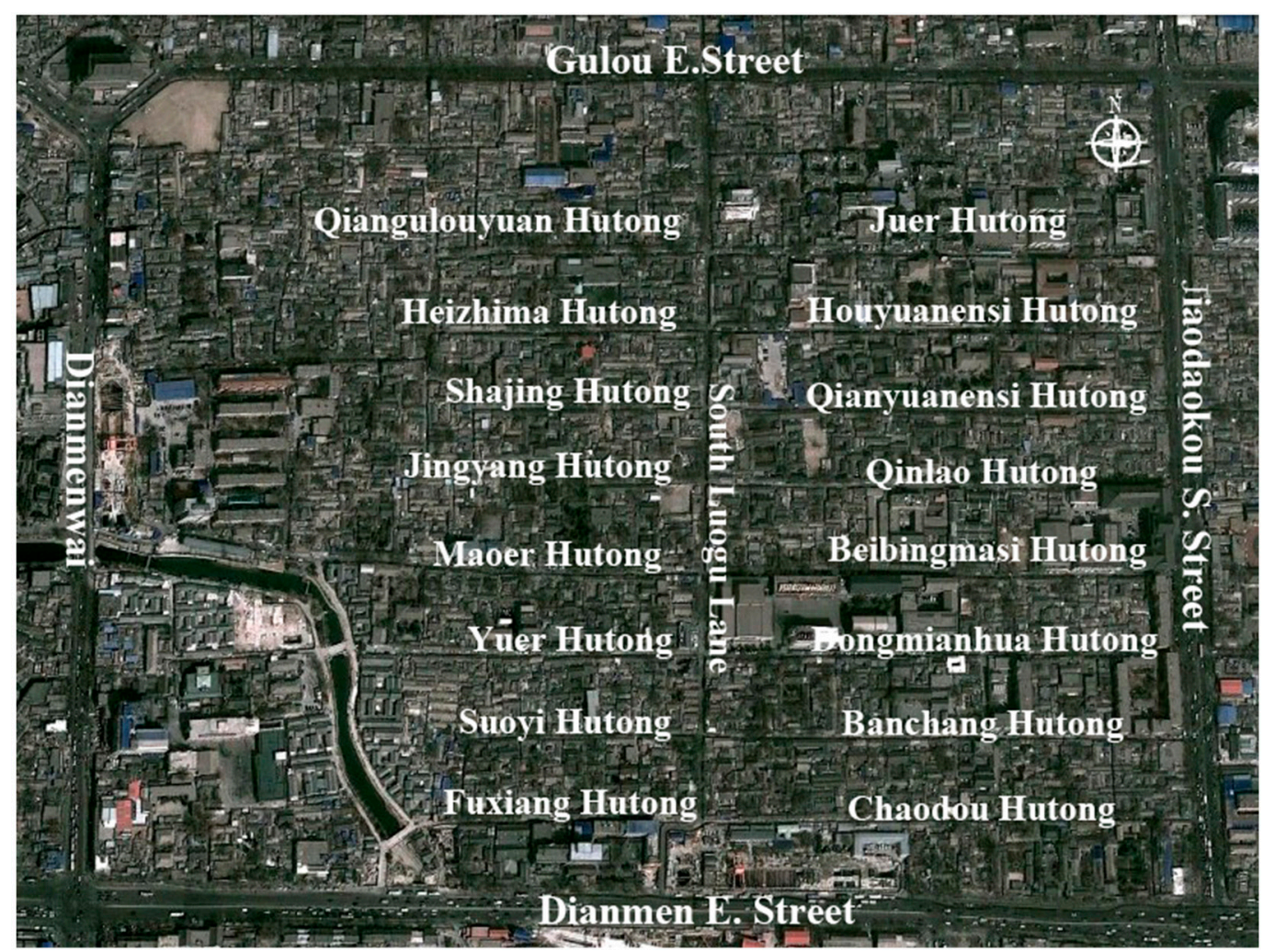

Figure 2. The area of SLL and the Hutongs in it.

In 1990, SLL was included in a list of 25 historical and cultural districts in the old city of Beijing. Between 2005 and 2007, the Urban Planning and Design Center at Peking University and the sub-district office of Jiaodaokou jointly compiled the "Jiaodaokou SLL conservation and development plan", which envisioned a transformation of SLL [23]. In 2011, it was designated a 3A-level scenic destination by the National Tourism Administration [24]. 
Part of the reason why SLL has attracted so much attention is that many of China's cultural and political elites have lived there, including the artist Baishi Qi (1864-1957) and the writer Mao Dun (1896-1981). The former houses of these elites retain a certain historical and cultural significance in the popular imagination. The area of the elites' former homes in SLL is shown in Figure 3.

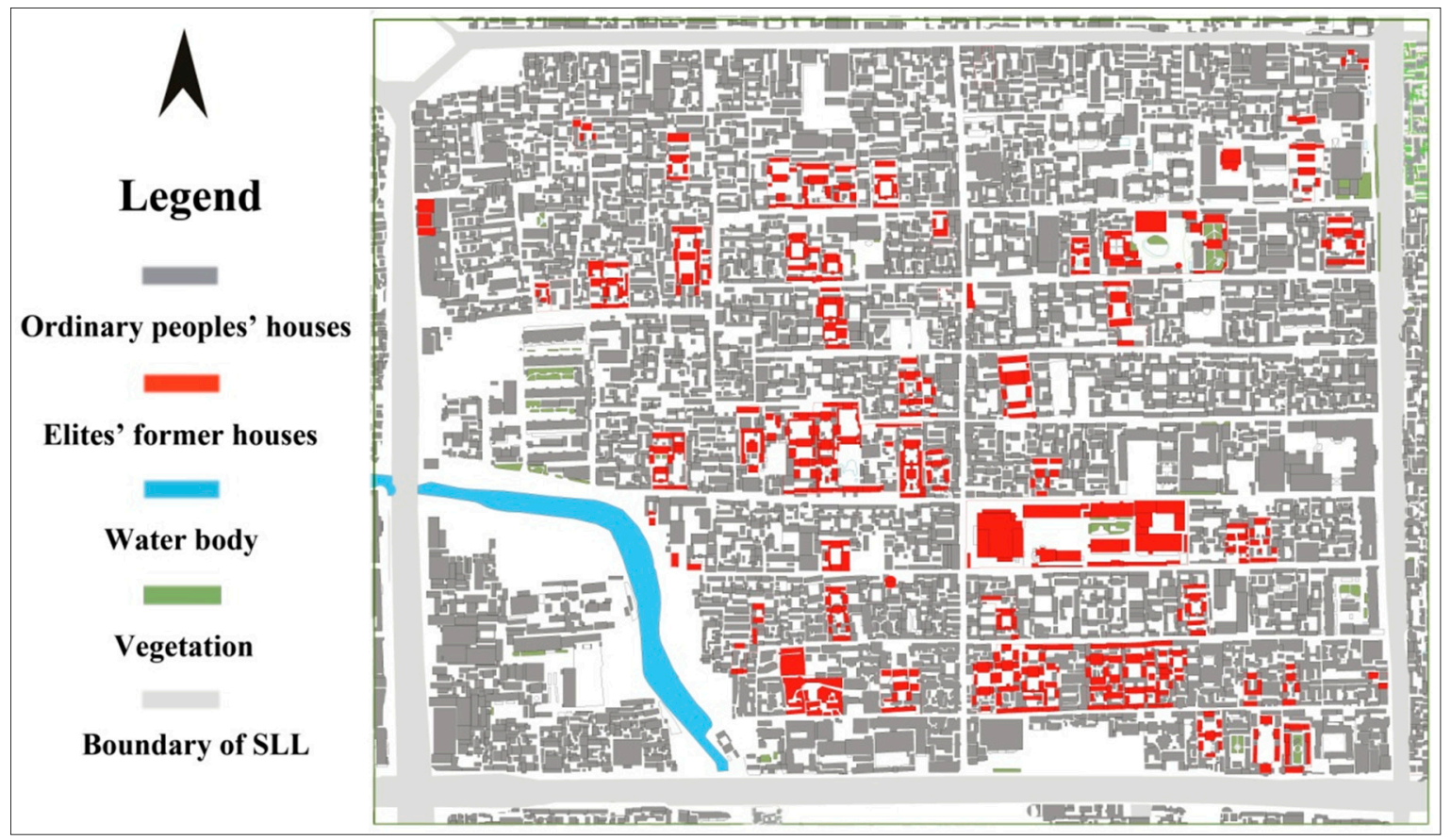

Figure 3. The area of the elites' former homes in SLL.

Because it is an old, elite residential area, place-making has been spurred by investment in housing construction and repair. Studying changing investments in elites' former houses therefore forms the central part of our analysis. In the following sections, we explore these changes over the course of four historical periods.

\section{From the Yuan Dynasty to the Mid-Qing Dynasty (before 1850)}

\subsection{Property Regimes and Capital Flows}

During this period, a pure, private property regime was the primary Chinese urban land system [25] (pp. 17-19). When the capital city was completed during the Yuan Dynasty, most state officials and elites wanted to move there. They were mostly wealthy and prominent figures [26] (p. 3). According to official records, the property regime that existed from the Yuan to the mid-Qing Dynasty allowed the state treasury to invest in the houses of high-ranking people. Throughout the Yuan Dynasty, the government built most of the housing for members of the imperial court and for dignitaries, while housing for common people was built at their own expense. According to regulations, each household could own no more than 8 acres (about 5300 square meters) of land. However, because of inequalities in asset allocations, the scale of the homes varied greatly [26] (p. 4). In the Yuan Dynasty, therefore, most homes in the SLL area were luxury houses built by the government, though common people also built more modest houses. In the Ming Dynasty, SLL was also a gathering place for members of the 
royal family and generals [21] (p. 22). For example, according to the records of the ancient books TianZhiOuWen, a famous eunuch's nephew in the Ming Dynasty, Liangqing Wei, lived in a very large house in the eastern part of Shoubi Hutong [27].

In the early period of the Qing Dynasty, the imperial court gave an order to occupy the houses in the inner city for Bannermen [28]. Except for Manchu people, the people of Han and other ethnic groups had to move to the outer city [21] (pp. 179-180). According to the regulation, the place where people lived should be in accordance with their ethnicity and rank. Within the three types of main Bannermen, Manchu Bannermen lived closest to the city center, on the periphery were Mongol Bannermen, and outward from there were Han Bannermen. The highest-ranking officers lived closest to the center of the city.

SLL is adjacent to the imperial palace and has a superior geographical position, so it was the place where Manchurian officers and soldiers of Bordered Yellow Bannermen lived during the Qing Dynasty [21] (p. 6). They were considered to be one of the top three most powerful Bannermen. They were subjects of the crown prince and held prominent status [29]. According to the record of ancient books, Ri Xia Jiu Wen Kao and Chen Yuan Shi Lue, twelve lanes in SLL were the residences of senior officials in Bordered Yellow Bannermen [30,31]. According to the regulations of the Qing Dynasty, Bannermen in the inner city were provided houses in accordance with their grade [26] (p. 720). For example, Bushu Ye, the fourth son of Emperor Chongde in the Qing Dynasty [32], and Chengchou Hong, a military commander in the early years of the Qing Dynasty, lived in the western part of SLL [27,33]. They even received money from the state to repair their houses [26] (p. 20).

The government did not build all of the houses in SLL. Some residents built their own houses. Gradually, the number of houses built with private money of secretaries became far greater than the number allotted by the government [26] (pp. 7-8). For example, Prince Sengge Linqin (Sengge Rinchen), a nobleman known for his role during the Second Opium War and the suppression of the Taiping and Nian rebellions, originally owned just the houses to the west of Chaodou Hutong. However, in 1826 he used 6690 silver coins to buy 117 houses in the 77th courtyard of Chaodou Hutong. He then invested in reconstruction, and the rebuilt houses, together with the originals, formed a mansion with the eastern, central and western homes consisting of four yards, respectively. According to the record of Yan Du Cong Kao, the mansion of Sengge Rinchen was located in Chaodou Hutong.

\subsection{Place Image: Residential Quarter for High-Ranking Officials}

The image of SLL before mid-Qing Dynasty was a residential quarter for high-ranking officials, and it did not change since the early 13th century when the Yuan Dynasty was established. During this period, capital accumulation in SLL meant that the density of elites' houses was higher than in other residential districts in the city. Figure 4 shows that SLL was highly concentrated with elites' former houses in Beijing before the mid-Qing Dynasty (the density of elites' former houses in SLL was 4.76 units per square $\mathrm{km}$ ).

The state gave residents of SLL money to maintain certain architectural features. This indicates their cultural preference and social status. The buildings and decorative style were vaunted as highlighting local culture. For example, the QueTi (a decoration on the top of gate frame) and Men Dun (a pair of stones for holding spindles) on the gate in front of Liangqing Wei's residence came to be seen as a fine representation of the traditional culture of Beijing's quadrangles. The brick carving on Feng Shan's 
residence was viewed as an important architectural piece. These investments improved the quality of many of the traditional courtyards, houses, beautiful gardens, and stone inscriptions in Beijing (as shown in Figure 5). Due to these investments, the elites' former houses convey unique narratives. The investments also made the courtyards form regular and orderly, ritual courtyard spaces. In these spaces, there is a clear distinction regarding which rooms the older men and the younger men would live in, and the distinction reflects traditional Chinese culture. The placing of objects in the courtyard also reflects traditional culture. The investments formed a unique architectural culture and, indirectly, also formed a harmonious neighborhood relationship.

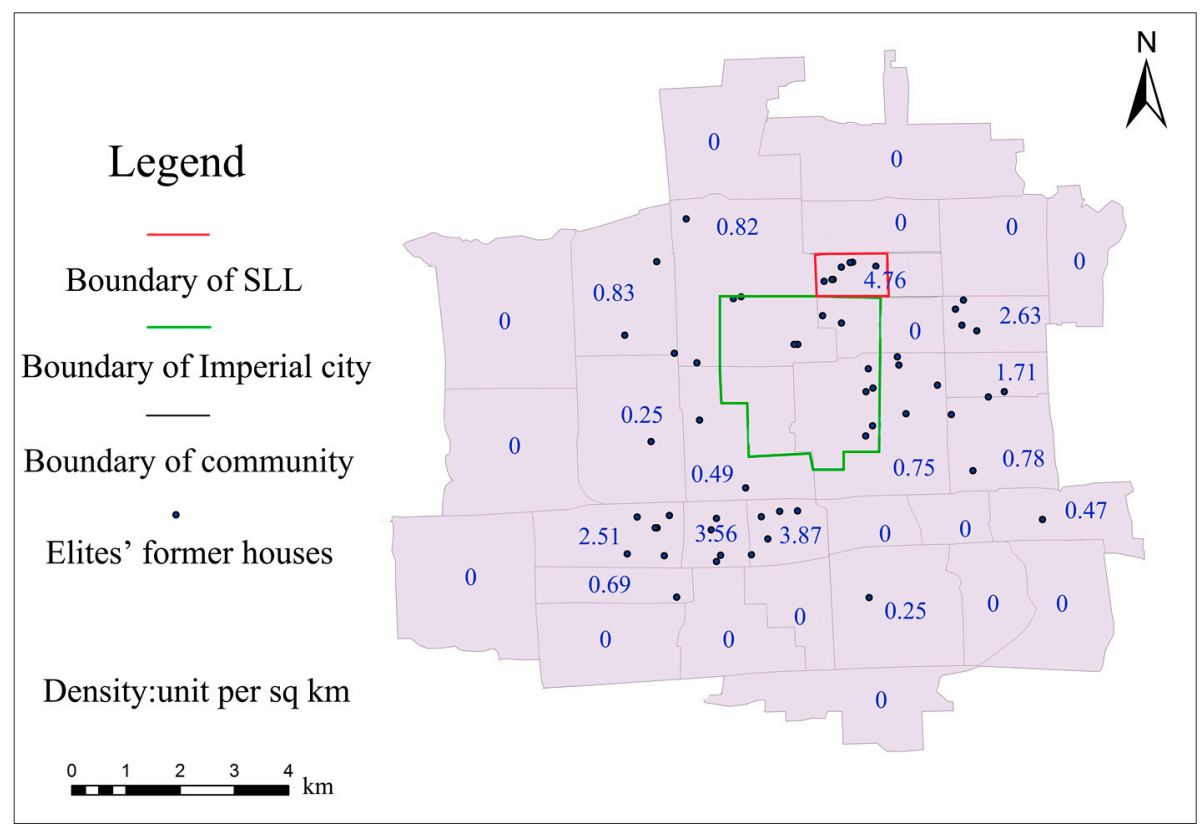

Figure 4. The density of elites' former houses in the city before mid-Qing Dynasty.

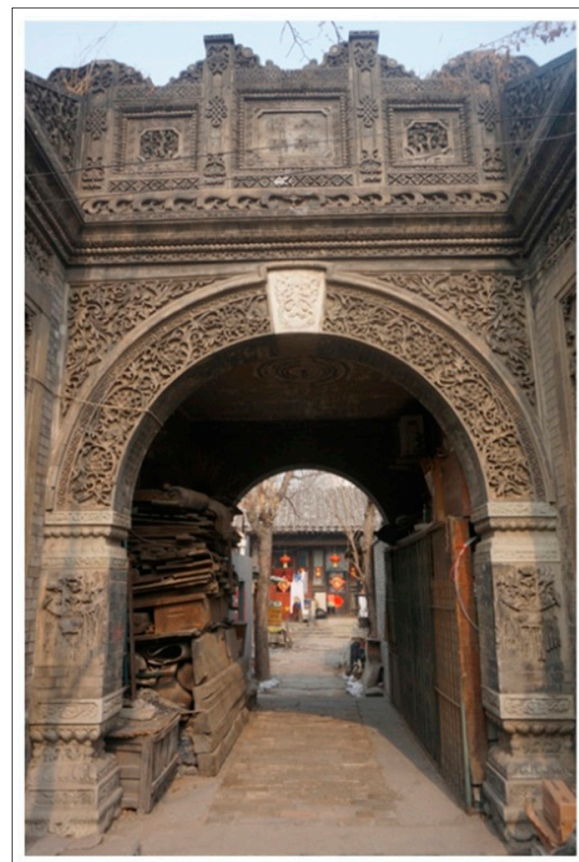

Feng Shan's former house with Chuihua Gate

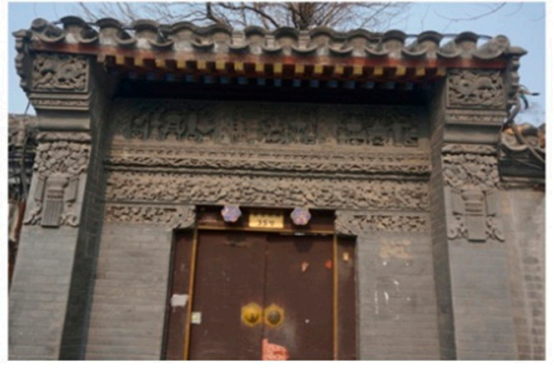

Ming Shan 's former house with Chuihua Gate

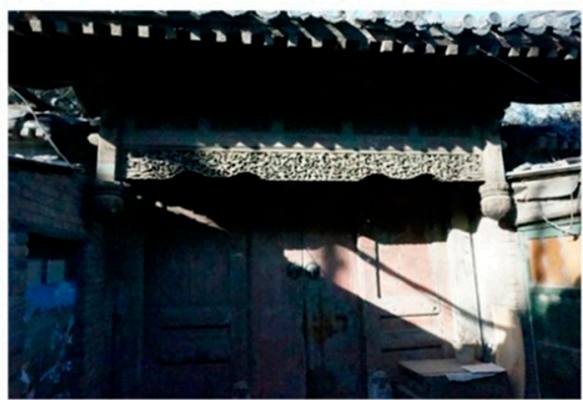

Wan Rong 's former house with Courtyard Gate

Figure 5. Some traditional and beautiful courtyards in SLL. 


\section{From the Late Qing Dynasty to 1949 (1851 to 1949)}

\subsection{Property Regimes and Capital Flows}

During this period, the urban land system remained primarily a private property regime [25] (pp. 18-19). However, with the decline of the Qing Dynasty, the government's economic status slipped. Most of the Bannermen who had previously received support from the imperial court had to sell their houses because of economic pressure. Most of the elites' former estates were divided and sold by the Bannermen. Government investment in the houses of elites in SLL declined, so the majority of new expenditure had to come from private sources. The large-scale and decorated quadrangles attracted some new elites to move in.

Rich people did buy some of the larger and more opulent houses in SLL, which remain intact today. During this period, there were still large families, elites and dignitaries living in SLL [21] (p. 159). For example, after Sengge Rinchen died, his sons and grandsons continued to expand his houses through investment. The mansion crossed over Chaodou Hutong and Banchang Hutong, and consisted of six sections, each containing four courtyards, forming huge buildings of more than 200 houses [21] (pp. 70-74). Acting-President Guozhang Feng bought houses at numbers 7, 9, 11, 13 in Mao'er Hutong and invested in the installation of plumbing and electricity. Mao'er Hutong is typical of where many of the elites lived [21] (p. 131), and the property was under the private ownership of Wen Yu, a scholar of the late Qing Dynasty. Among them, No. 7 was a horse stable, No. 9 was called Ke Garden, and No. 11 and 13 were residential areas of the owner's family, which respectively consisted of five quadrangles. Wen Yu thought the place was quiet and unique [34]. The Ke Garden was considered the most artistic private garden of the late Qing Dynasty in Beijing [35,36]. During the period of Japanese occupation, Lanfeng Zhang (the commander of the puppet army in Beijing) bought this property [21] (p. 73-84).

Some houses in SLL did receive occasional investments by common people. The government also invested in public infrastructure. For example, in the 9th year of the Republic of China (1919), Beijing's municipal government reconstructed the roads of Mianhua Hutong, SLL Street and Mao'er Hutong. The total investment was 2344.71 "Silver Yuan" [37]. Among the elites' former houses, Rong Yuan's residence benefited from government investments. Rong Yuan was the father of the last queen. The government still supported a luxurious life for the last emperor who had been deposed from his throne. It invested heavily in the large-scale rebuilding of his houses in preparation for the last queen's wedding in 1922.

Some of the changes to the elites' former houses and their investments from the first to the second period can be seen in Table 1. This table shows that investment in many elites' houses during the second period came primarily from individuals. 
Table 1. Changes in ownership and investment for elites' former houses in SLL from the first period to the second period.

\begin{tabular}{|c|c|c|c|c|}
\hline \multirow[b]{2}{*}{ Address } & \multicolumn{2}{|c|}{ The First Period } & \multicolumn{2}{|c|}{ The Second Period } \\
\hline & $\begin{array}{l}\text { Housing Ownership's } \\
\text { Elite and His/Her Identity }\end{array}$ & Investment & $\begin{array}{l}\text { Housing Ownership's } \\
\text { Elite and His/Her Identity }\end{array}$ & Investment \\
\hline \multirow{3}{*}{$\begin{array}{l}\text { No. } 7,9,11,13 \text { in } \\
\text { Mao'er Hutong }\end{array}$} & & & $\begin{array}{l}\text { During the late Qing Dynasty: Wen Yu } \\
\text { (a minister of the Interior) }\end{array}$ & Private investment for construction \\
\hline & & & $\begin{array}{l}\text { 1917-1936: Guozhang Feng (The agency } \\
\text { president of Beiyang government) }\end{array}$ & $\begin{array}{l}\text { 1917-1936: Private investment for } \\
\text { installing water apparatus and lamps }\end{array}$ \\
\hline & & & $\begin{array}{l}\text { 1937-1945: Lanfeng Zhang } \\
\text { (A commander of puppet army) }\end{array}$ & $\begin{array}{l}\text { 1937-1945: Private investment for } \\
\text { renovation and redecoration }\end{array}$ \\
\hline $\begin{array}{l}\text { No. } 35,37 \text { in } \\
\text { Mao'er Hutong }\end{array}$ & & & Rong Yuan (the father of the last queen) & $\begin{array}{l}\text { Private investment for construction, } \\
\text { The government invested heavily in } \\
\text { renovation, repair }\end{array}$ \\
\hline $\begin{array}{l}\text { No. } 73,75,77 \text { in } \\
\text { Chaodou Hutong }\end{array}$ & $\begin{array}{l}\text { Sengge Rinchen } \\
\text { (a nobleman) }\end{array}$ & $\begin{array}{l}\text { Private investment } \\
\text { for expansion }\end{array}$ & $\begin{array}{l}\text { Jiajin Zhu (A famous expert } \\
\text { of cultural relics and the history) }\end{array}$ & Private investment for redecoration \\
\hline \multirow{2}{*}{$\begin{array}{l}\text { No.7 in } \\
\text { Qiangulouyuan } \\
\text { Hutong }\end{array}$} & \multirow{2}{*}{$\begin{array}{l}\text { Tu Qin Bao (a leader of } \\
\text { yellow Bannermen) }\end{array}$} & \multirow{2}{*}{$\begin{array}{l}\text { Government } \\
\text { investment for } \\
\text { construction }\end{array}$} & $\begin{array}{l}\text { 1911-1926: Zhaoxiang } \mathrm{Wu} \\
\text { (A famous merchants) }\end{array}$ & $\begin{array}{l}\text { Private investment for renovation } \\
\text { and redecoration }\end{array}$ \\
\hline & & & $\begin{array}{l}\text { 1927-1949: Shoushan Song } \\
\text { (A senior general of Dongbei troops) }\end{array}$ & $\begin{array}{l}\text { Private investment for renovation } \\
\text { and repair }\end{array}$ \\
\hline No.59,65 in SLL & $\begin{array}{l}\text { Chengchou Hong (a military } \\
\text { commander at the beginning } \\
\text { of the Qing Dynasty) }\end{array}$ & & $\begin{array}{l}\text { Wenzhong Pei (an archaeologist and, } \\
\text { a paleontologist) }\end{array}$ & \\
\hline \multirow{2}{*}{$\begin{array}{l}\text { No. } 13 \text { in } \\
\text { Heizhima Hutong }\end{array}$} & & & $\begin{array}{l}\text { Kui Jun (a ministry of Justice, } \\
\text { one of the four most wealthy) }\end{array}$ & \\
\hline & & & Mengyu Gu (A well-known politician) & $\begin{array}{l}\text { Private investment for renovation } \\
\text { and repair }\end{array}$ \\
\hline $\begin{array}{l}\text { No. 7, } 9 \text { in } \\
\text { Houyuanensi Hutong }\end{array}$ & & & Zai Fu (a descendant of the royalty) & Private investment for construction \\
\hline $\begin{array}{l}\text { No. } 35 \text { in } \\
\text { Qinlao Hutong }\end{array}$ & & & $\begin{array}{l}\text { Ming Shan } \\
\text { (from the Ministry of the Interior) }\end{array}$ & $\begin{array}{l}\text { Private investment for expansion, } \\
\text { then divided and sold }\end{array}$ \\
\hline
\end{tabular}


Table 1. Cont.

\begin{tabular}{|c|c|c|c|c|}
\hline \multirow[b]{2}{*}{ Address } & \multicolumn{2}{|c|}{ The First Period } & \multicolumn{2}{|c|}{ The Second Period } \\
\hline & $\begin{array}{c}\text { Housing Ownership's } \\
\text { Elite and His/Her Identity }\end{array}$ & Investment & $\begin{array}{l}\text { Housing Ownership's Elite } \\
\text { and His/Her Identity }\end{array}$ & Investment \\
\hline No.15 in Dongmianhua Hutong & Feng Shan (a general) & $\begin{array}{l}\text { Private investment } \\
\text { for renovation }\end{array}$ & Unknown (divided and sold) & \\
\hline No.15,17,19 in Shajing Hutong & & & $\begin{array}{l}\text { Kui Jun (from the Ministry of Justice, } \\
\text { One of the four most wealthy) }\end{array}$ & Private investment for construction \\
\hline No.17 in Beibingmasi Hutong & $\begin{array}{l}\text { Ling Gui } \\
\text { (from the Ministry of Personnel) }\end{array}$ & & Erxi Zhao (a history museum curator) & Private investment for redecoration \\
\hline No. 13 in Yu'er Hutong & $\begin{array}{l}\text { Bushu Ye (the Emperor } \\
\text { Huang Taiji's fourth son) }\end{array}$ & & $\begin{array}{l}\text { Shuping Dong (the chairman of the } \\
\text { Beihai Park Board) }\end{array}$ & $\begin{array}{l}\text { Private investment for renovation } \\
\text { and redecoration }\end{array}$ \\
\hline $\begin{array}{l}\text { No.3, } 5 \text { in Ju'er Hutong, } \\
\text { No.6 in Shoubi Hutong }\end{array}$ & & & $\begin{array}{l}\text { RongLu } \\
\text { (from the Ministry of the Interior) }\end{array}$ & Private investment for construction \\
\hline No.18 in Qinlao Hutong & & & 1940-1944: Duo Erjie (a nobleman) & \\
\hline $\begin{array}{l}\text { No.39 in } \\
\text { Dongmianhua Hutong }\end{array}$ & & & $\begin{array}{l}\text { Yunpeng Jin (the Acting Minister in } \\
\text { the Republic of China) }\end{array}$ & $\begin{array}{l}\text { Private investment for repair and } \\
\text { renovation }\end{array}$ \\
\hline $\begin{array}{l}\text { No.10,12 in } \\
\text { Suoyi Hutong }\end{array}$ & & & $\begin{array}{l}\text { Jinsheng Wang (a successful man in } \\
\text { the gold business) }\end{array}$ & Private investment for construction \\
\hline No. 2 in Qiangulouyuan Hutong & & & Ruqin Wang (a general) & \\
\hline No. 1 in Houyuanensi Hutong & & & Lianying Li (a famous eunuch) & Private investment for construction \\
\hline No. 45 on Dianmen east street & BaoQuan (a Sanyi minister) & & & \\
\hline No. $7,9,11$ in Shoubi Hutong & $\begin{array}{l}\text { Liangqing Wei (a famous } \\
\text { eunuch's nephew in the } \\
\text { Ming Dynasty) }\end{array}$ & & & \\
\hline
\end{tabular}




\subsection{Place Image: A High-Income Residential Area}

The image of SLL changed during this period, as it came to be seen as a residential area for high-income or wealthy people. This is mainly because the capital invested in houses was not primarily from the government. Many rich families bought the houses from former officials. Figure 6 shows that SLL was still the most concentrated area of elites' former houses in the late Qing Dynasty. The density actually increased from the mid-Qing Dynasty to late-Qing Dynasty. The comparison of Figures 4 and 6 illustrates that prior capital investment in houses in SLL influenced subsequent capital flows. The layer of capital accumulation during the first period attracted another layer of private investment during the second period. This phenomenon fits with Massey's theory that place is the product of numerous layers that articulate socio-economic relations over time [38] (pp. 186-188). Over time, these layers form a sense of place that is seen as distinct in relation to larger regional divisions [39]. SLL gradually became a more culturally important district compared to other communities surrounding the imperial city. For example, Kui Jun's exquisite residence came to be regarded as a beautiful symbol of the Beijing courtyard, and would later appear on many TV programs. The Chuihua gates and exquisite carvings in Wan Rong's house were valued for possessing a quality rarely seen in Beijing (see Figure 5). The data also reveals that cultural relics associated with contemporary SLL come primarily from the elites' former houses [40]. The elites living here invested large sums of money in constructing new buildings in their courtyards and repairing or decorating them.

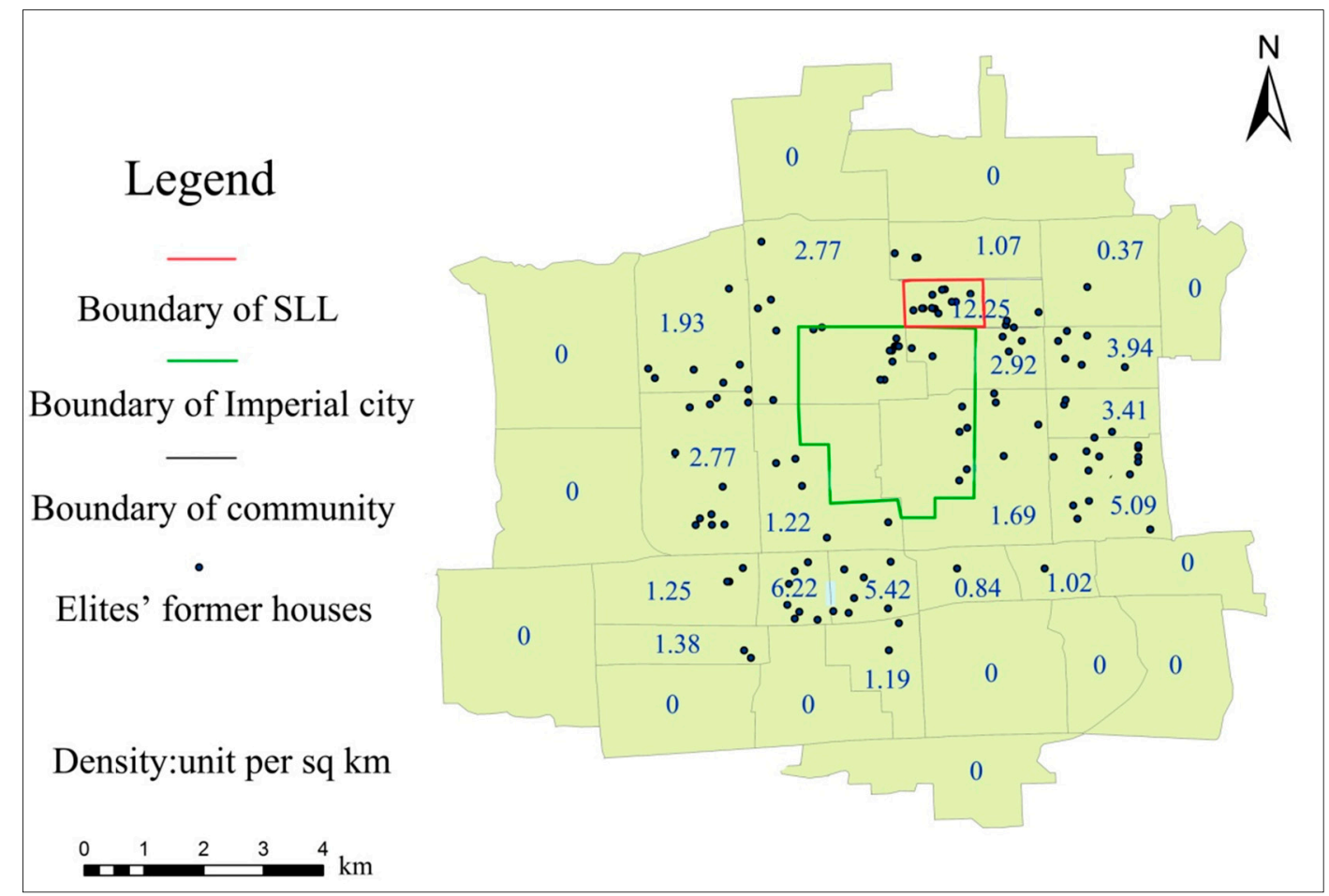

Figure 6. The density of elites' former houses in the city during the late Qing Dynasty. 


\section{A Fundamental Property Regime Revolution (1949 to 1978)}

\subsection{Property Regimes and Capital Flows}

After the founding of the People's Republic of China (PRC) in 1949, the government carried out major land reforms. It announced that it would confiscate the land owned by foreign imperialists, the Kuomintang government, and bureaucratic capitalists. This land became governmental property, which was used for housing government agencies, people's organizations, state-owned industrial and commercial enterprises, and national staff members. At the same time, for people who were self-employed workers and urban residents, private ownership of land was still recognized [41] (pp. 184-185), [42] and [43] (pp. 68-72). In 1954, private ownership of land was still the primary property system stipulated in the first Constitution of PRC. In 1956, however, the Central Committee of the Communist Party of China issued "The Opinion on the Present Situation of City Private Real Estate and Socialist Transformation", and implemented a socialist transformation of private real estate with the overall goal of strengthening state control of housing and advancing national ownership. The government rented the houses to residents in the city. The government was responsible for maintenance but did not have sufficient resources, so the houses deteriorated. A public-private partnership scheme was implemented for housing, although its provisions still allowed for the existence of private property rights in some cases [43] (pp. 10-11) and [25] (pp. 99-100). Nevertheless, by 1958, 90\% of the urban land and the houses on that land had been nationalized [43] (pp. 77-78) and [44]. Less money was invested in the houses during this period because of the property ownership changes.

From 1958 to 1978, a program of planned distribution was initiated. Land users did not need to pay a land premium or rent, and there was no defined use period for them. The transfer of land use rights was abolished, however, and the allocation of land resources was done exclusively through a mandatory administrative plan [45]. The 1975 and 1978 Constitutions did not explicitly abolish the private ownership of urban land [41] (p. 185) and [43] (pp. 68-72). Urban individuals who had residential and urban land were still entitled to their ownership and use rights. However, everything was coordinated and allocated by the government. The company welfare housing system was implemented in the city, whereby the state invested heavily in the construction of housing. Workers applied for the allocation of public housing through the company. For each company, the corresponding area of housing was allocated free of charge to employees living according to their status and their duties, seniority, family size or other conditions [46].

During this period, all real estate to be produced and distributed was included in the state's project plan. Ownership and use rights for private homes were denied without any real justification. Private houses, especially those owned by capitalists, were almost all reassigned to the public [41] (p. 185). In the meantime, the houses were uniformly distributed and maintained by the government [42] (pp. 4-5) and [43] (pp. 68-72).

During this early period of the founding of New China, the military authority and Government Offices Administration of the State Council (GOASC) confiscated the houses of some former military officials and bureaucrats in SLL. They then became residences for some high-ranking cadres of the Chinese Communist Party [47]. Some officials lived there during this time. The number of properties labeled as elites' former houses increased after 1949 (see Table 2). The government also set up embassies in some 
residences, such as the former Yugoslavian Embassy, which was located in the Zai Fu residences in No. 7 in Houyuanensi Hutong [21] (pp. 50-52). Investment in elites' former houses, which had been confiscated and redistributed, came primarily from the government.

Table 2. The increased elites' former houses after 1949 in SLL.

\begin{tabular}{llc}
\hline \multicolumn{1}{c}{ Address } & \multicolumn{1}{c}{ Elites } & Time \\
\hline No.31 in Yuer Hutong & Ronghuan Luo (A grand marshal) & After 1949 \\
\hline No.33 in Yuer Hutong & Yu Su (A general) & After 1950 \\
\hline No.13 in Yuer Hutong & Baishi Qi (A painter) & $1955-1956$ \\
\hline No.11 in Fuxiang Hutong & $\begin{array}{l}\text { Shuchang Wang (A member of the } \\
\text { CPPCC National Committee) }\end{array}$ & $1949-1960$ \\
\hline No.13 in Houyuanensi Hutong & Dun Mao (a famous writer) & $1974-1991$ \\
\hline No.2 in Suoyi Hutong & Ren Pu (The younger brother of the last Emperor of China) & After 1975 \\
\hline No.84 on Di'anmen East Street & Youxun Wu (A physical scientist) & After 1949 \\
\hline
\end{tabular}

During the 1958-1966 period, the government rented some residences in SLL (a method of socialist transformation) but invested little in the houses. During the Cultural Revolution (1966-1976), some houses were occupied and some were destroyed. From 1949 to 1978, repair departments of the government provided housing repairing. At this point, the capital flow to the houses was limited, and it could not flow freely. The government invested in housing repairs according to the mid-1950s' policy, which was to ensure safety, reasonable maintenance, and focus on improvements. At the beginning of the 1960s, the guidelines were to eliminate leaks and strengthen repairs, guaranteeing normal use and improvements according to need [26] (pp. 311-313). Some of the homes that were occupied by embassies also received investment, and a smaller amount was invested in municipal engineering. This included money for constructing artificial facilities, renovating and repairing roads and sewers, and installing water stations [48].

\subsection{Place Image: A Mixed-Income Residential Area}

The image of SLL changed completely as a result of the land property reform. It became a mixed-income residential area. There was almost no capital from the government or private sources invested in the houses, including those houses belonging to state or city. Due to changes in family structure and growing population density, housing demand was increasing. In 1974, the central authorities encouraged individuals to build houses in order to mobilize enthusiasm for housing construction from the institutes. The residents of SLL made use of every corner of a residential courtyard building. In the late 1970s, with the national promotion of "expanding housing areas appropriately", residents built their own shacks in the courtyards [26] (pp. 50-52). In addition, after the Tangshan earthquake in 1976, some residents built earthquake sheds in the courtyard, which later became houses. This, coupled with the impact of the Cultural Revolution, led the quality of some elites' former houses in SLL to decline, especially in terms of aesthetics. Overall, from the second period to the third period, the density of elites' former houses in SLL declined and it was no longer the most significant residential area within Beijing (see Figure 7). 


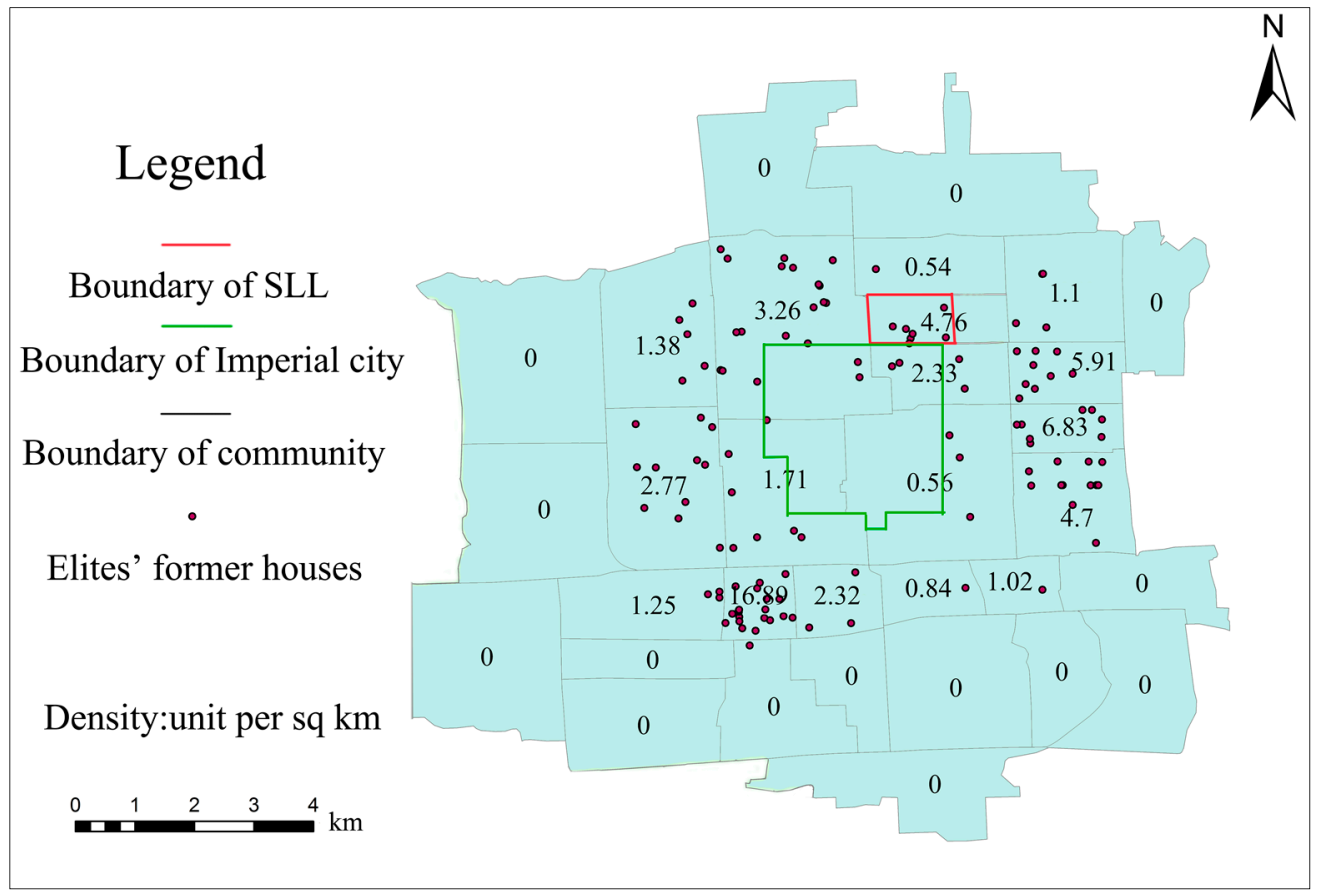

Figure 7. The density of elites' former houses in the city during 1949-1978.

\section{Property RegimeTransformationPost-1978}

\subsection{Property Regimes and Capital Flows}

The housing market today comprises multiple forms of property regime. After 1978, when China began its reforms and opened up more to the global economy, the property system changed. Although public ownership dominates, various forms of ownership coexist. Urban land in China had gone through a period of being free to use, without circulation, and with no time limits on use. It has since been gradually commodified and subject to time limits. Land-use fees were first imposed in 1979 [49]. After that, governments at all levels began to return the houses that belonged to private owners before the early 1950s. Meanwhile, individual owners also regained land-use rights [41] (pp. 187-188). Consequently, some houses in SLL belong to the government, some belong to specific departments, and some belong to individuals.

In May 1985, the Municipal People's Government of Beijing promulgated the "provisional regulations on the land use fees of sino-foreign joint venture enterprise of Beijing". In April 1988, the National People's Congress (NPC) regulated that "the right to land-use may be transferred in accordance with the provisions of the law" through amendments to the constitution. In December of that same year, it announced the implementation of "provisional regulations of urban land-use tax of the PRC", establishing the government's plan to levy a land-use tax [50-52].

During this period, only a few elites' former houses that were under private ownership received private investment, while the others received almost no investment at all. The government's investments in SLL focused mainly on tourism and construction for business improvement. Following the property regime reforms, the Government Offices Administration of the State Council (GOASC) now owns some large residencies (Ke Garden and the No. 9,11 in Mao'er Hutong, for example), while others belong to 
the Housing Administration Bureau(HAB). Still others belong to state departments. Table 3 shows how multiple forms of ownership coexist in SLL.

Table 3. The ownership of the elites' former houses and their utilization after 1978.

\begin{tabular}{|c|c|c|c|}
\hline Address & Elites & Ownership after 1978 & Utilization \\
\hline \multirow[b]{2}{*}{ No. $7,9,11,13$ in Maoer Hutong } & \multirow{2}{*}{$\begin{array}{c}\text { Wen Yu, } \\
\text { Guozhang Feng, } \\
\text { Lanfeng Zhang }\end{array}$} & $\begin{array}{c}\text { 7-Housing Administration } \\
\text { Bureau (HAB) }\end{array}$ & 7-Tenement housing \\
\hline & & $\begin{array}{c}\text { 9,11,13-Government Offices } \\
\text { Administration of the State } \\
\text { Council (GOASC) }\end{array}$ & 9,11,13-Unoccupied \\
\hline \multirow{2}{*}{ No. 35, 37 in Maoer Hutong } & \multirow{2}{*}{ Rong yuan } & \multirow{2}{*}{ Department } & 37-Tenement housing \\
\hline & & & 35-Unoccupied \\
\hline \multirow{2}{*}{ No. $73,75,77$ in Chaodou Hutong } & \multirow{2}{*}{$\begin{array}{l}\text { Sengge Rinchen, } \\
\text { Jiajin Zhu } \\
\end{array}$} & 73-department & \multirow{2}{*}{ Tenement housing } \\
\hline & & 75,77-GOASC & \\
\hline No.7 in Qiangulouyuan Hutong & $\begin{array}{c}\text { Tuchyn Bao, } \\
\text { Zhaoxiang Wu, } \\
\text { Shoushan Song }\end{array}$ & GOASC & Commercial use \\
\hline \multirow[b]{2}{*}{ No. 59, 65 in SLL } & \multirow[b]{2}{*}{$\begin{array}{l}\text { Chengchou Hong, } \\
\text { Wenzhong Pei }\end{array}$} & \multirow[b]{2}{*}{ Private } & Parts are tenements \\
\hline & & & $\begin{array}{c}\text { Parts are for } \\
\text { commercial use }\end{array}$ \\
\hline No.13 in Heizhima Hutong & $\begin{array}{l}\text { Kui Jun, } \\
\text { Mengyu Gu }\end{array}$ & GOASC & Tenement Housing \\
\hline No.7.9 in Houyuanensi Hutong & Zai Fu & GOASC & Unoccupied \\
\hline No.35 in Qinlao Hutong & Ming Shan & GOASC & Single-familyhousing \\
\hline No.15 in Dongmianhua Hutong & Feng Shan & HAB & Tenement housing \\
\hline No.15,17,19 in Shajing Hutong & Kui Jun & $\mathrm{HAB}$ & Tenement housing \\
\hline No. 17 in Beibinmasi Hutong & $\begin{array}{l}\text { Ling Gui, } \\
\text { Erxun Zhao }\end{array}$ & Private & Shops \\
\hline No. $11,13,15$ in Yu'er Hutong & $\begin{array}{c}\text { Bushu Ye, } \\
\text { Shuping Dong, Baishi Qi }\end{array}$ & Department & Museum \\
\hline \multirow{2}{*}{$\begin{array}{l}\text { No. 3, 5, } 7 \text { in Ju'er Hutong, } \\
\text { No. } 6 \text { in Shoubi Hutong }\end{array}$} & \multirow{2}{*}{ Rong Lu } & 7-private & \multirow{2}{*}{ Dwelling } \\
\hline & & 3,5,6-GOASC & \\
\hline No. 39 in Dongmianhua Hutong & Yunpeng Jin & Department & Building for education \\
\hline No.31 in Yu'er Hutong & Ronghuan Luo & GOASC & Single-family housing \\
\hline No.33 in Yu'er Hutong & $\mathrm{Yu} \mathrm{Su}$ & GOASC & Single-family housing \\
\hline No.11 in Fuxiang Hutong & Shuchang Wang & HAB & Tenement housing \\
\hline No.13 in Houyuanensi Hutong & Dun Mao & GOASC & Museum \\
\hline No.7, 9,11 in Shoubi Hutong & Liangqing Wei & GOASC & Tenement housing \\
\hline No.18 in Qinlao Hutong & Duo Erji & Demolition & Demolition \\
\hline No.57 in Beibingmasi Hutong & Longyou Xiao & $\mathrm{HAB}$ & Dwelling \\
\hline No.84 on Di'anmenEast Street & Youxun $\mathrm{Wu}$ & HAB & Dwelling \\
\hline No.2 in Qiangulouyuan Hutong & Ruqin Wang & Private & Single-family housing \\
\hline \multirow{2}{*}{ No. 15, 17 in Fuxiang Hutong } & \multirow{2}{*}{ Jinsheng Wang } & 15-HAB & \multirow{2}{*}{ Tenement housing } \\
\hline & & 17-department & \\
\hline
\end{tabular}


Table 3. Cont.

\begin{tabular}{lccc}
\hline Address & Elites & Ownership after 1978 & Utilization \\
\hline \multirow{2}{*}{ No.10,12 in Suoyi Hutong } & Jinsheng Wang & \multirow{2}{*}{ HAB } & 10 Single-family housing \\
\cline { 4 - 4 } & & Department & 12 Tenement housing \\
\hline No.1 in Houyuanensi Hutong & Lianying Li & & Tenement housing \\
\hline No.45 on Di'anmen East Street & Bao Quan & Private & Single-family housing \\
\hline No.2 in Suoyi Hutong & Ren Pu &
\end{tabular}

Only a small number of houses under private ownership have received private investment. The residences occupied by the offspring of elites (e.g., SuYu and Ronghuan Luo's former houses) and the memorial residences (Baishi Qi's and Dun Mao's former houses), have received some money on a yearly basis from the government for repairs and courtyard renovations. In terms of the GOASC residences that had become warrens and the residences that belong to HAB, the government has rarely funded repairs. A recent survey revealed that no repairs were funded by the government for HAB houses or for houses owned by the departments until 2010 [53] (p. 102). Instead, these repairs have depended on private investment and small investments from the departments [53] (pp. 103-105). Government investments in SLL have focused mainly on municipal engineering, landscape renovation of the streets and Hutong, environmental remediation, tourism and construction for business improvements and to improve the cultural atmosphere, subsidies for commercial activities, and so on. An overview of government investments is shown in Table 4. SLL has now become a major tourism and business area in Beijing. Capital flows to SLL come from all over the world in the name of maintaining a unique "local" culture.

Table 4. The list of government investments in SLL.

\begin{tabular}{|c|c|c|c|}
\hline Year & Amount of Investment & Investment Direction & Specific Content \\
\hline $1996[54]$ & & Environmental remediation & Ju'er Hutong's remediation \\
\hline $1997[55]$ & $\begin{array}{c}\text { More than } 8 \text { million } \mathrm{RMB} \\
\text { (more than } 1.3 \text { million dollars) }\end{array}$ & $\begin{array}{l}\text { Municipal project, style } \\
\text { renovation }\end{array}$ & $\begin{array}{l}\text { Constructing the sewage of SLL, } \\
\text { renovating the courtyards protected areas }\end{array}$ \\
\hline \multirow{2}{*}{$1998[56]$} & $\begin{array}{c}2.03 \text { million RMB } \\
\text { (about } 0.326 \text { million dollars) }\end{array}$ & Environmental remediation & Remoulding 71 alley toilets \\
\hline & $\begin{array}{l}0.185 \text { million RMB } \\
\text { (about } 30000 \text { dollars) }\end{array}$ & Environmental remediation & Buying garbage collector cars \\
\hline $1999[57]$ & & Municipal project & Remolding the sewers \\
\hline $2000[58]$ & $\begin{array}{c}0.66 \text { million RMB } \\
\text { (about } 0.106 \text { million dollars) }\end{array}$ & Municipal project & Remolding the sewers \\
\hline $2001[59]$ & & & Installing of anti-theft system \\
\hline $2002[60]$ & & Style renovation & Improving the courtyard area environment \\
\hline $2003[61]$ & & Developing culture & Developing culture in Fuxiang Hutong \\
\hline $2005[62]$ & $\begin{array}{l}10 \text { million RMB } \\
\text { (about } 1.6 \text { million dollars) }\end{array}$ & Municipal project & Paving the way for SLL and laying pipes \\
\hline
\end{tabular}


Table 4. Cont.

\begin{tabular}{|c|c|c|c|}
\hline Year & Amount of Investment & Investment Direction & Specific Content \\
\hline \multirow{3}{*}{$2006[63]$} & $\begin{array}{l}5.66 \text { million RMB } \\
\text { (about } 0.909 \text { million dollars) }\end{array}$ & Municipal project & $\begin{array}{l}\text { Laying sewage pipeline and } \\
\text { telecommunication lines, changing military } \\
\text { communications line, laying the overhead } \\
\text { lines into the ground, installing } 4000 \mathrm{~m} \\
\text { security information transmission cable, } \\
\text { laying } 5000 \text { square meters antique brick. }\end{array}$ \\
\hline & $\begin{array}{l}3.1 \text { million RMB } \\
\text { (about } 0.498 \text { million dollars) }\end{array}$ & Style renovation & $\begin{array}{l}\text { Painting } 4500 \text { square meters walls, repairing } \\
\text { shops, demolishing } 63 \text { illegal buildings, } \\
\text { repairing } 120 \text { doors, windows and } 12 \text { gates, } \\
\text { clearing } 120 \text { unqualified boards, } \\
\text { getting rid of } 50 \text { old awnings, pruning trees } \\
\text { on both sides of the street, decorating parts } \\
\text { of the bars and businesses }\end{array}$ \\
\hline & $\begin{array}{l}\text { Less than } 2.5 \text { million RMB } \\
\text { (Less than } \\
0.401 \text { million dollars) }\end{array}$ & Style renovation & $\begin{array}{l}\text { Renovating synthetically SLL, } \\
\text { Ju'er Hutong, Qiangulouyuan HuTong, } \\
\text { Qianyuanensi Hutong and Houyuanensi } \\
\text { Hutong. Renovating the environment of } \\
\text { Jingyang Hutong and Shajing Hutong }\end{array}$ \\
\hline $2007[64]$ & & Municipal project & $\begin{array}{l}\text { Laying municipal engineering in } \\
10 \text { alleys and transformation project } \\
\text { for coal to electricity }\end{array}$ \\
\hline $2008[65]$ & & Municipal project & Renovation barrier-free facilities in SLL \\
\hline $2009[66]$ & & Municipal project & $\begin{array}{l}\text { Laying the overhead lines into the ground } \\
\text { in Fuxiang Hutong, Suoyi Hutong, } \\
\text { Jiangyang Hutong, Shajing Hutong, } \\
\text { Heizhima Hutong and Qiangulouyuan } \\
\text { Hutong. Removing } 40 \text { households, installing } \\
4 \text { box transformer substations and } 1 \text { opening } \\
\text { and closing device. }\end{array}$ \\
\hline \multirow{4}{*}{$2010[67]$} & & $\begin{array}{l}\text { Developing } \\
\text { tourism culture }\end{array}$ & $\begin{array}{l}\text { Organizing series of } \\
\text { folk cultural activities in SLL }\end{array}$ \\
\hline & & Style renovation & $\begin{array}{l}\text { Removing the unqualified plaques } \\
\text { and light boxes, repairing } 400 \text { square meters } \\
\text { floor areas. }\end{array}$ \\
\hline & $\begin{array}{l}\quad 200 \text { million RMB } \\
\text { (about } 32 \text { million dollars) [68] }\end{array}$ & Municipal project & $\begin{array}{l}\text { Laying municipal engineering in the west } \\
\text { of SLL, Putting } 3800 \mathrm{~m} \text { lines into the } \\
\text { ground, removing } 40 \text { households, } \\
\text { paving } 5800 \text { square meters roads. }\end{array}$ \\
\hline & $\begin{array}{l}25 \text { million RMB } \\
\text { (about } 4 \text { million dollars) }\end{array}$ & Commercial assistance & Subsidizing businesses \\
\hline $2011[69]$ & & $\begin{array}{l}\text { Developing tourism, } \\
\text { business culture }\end{array}$ & $\begin{array}{l}\text { Holding the second SLL Drama Festival, } \\
\text { improving management order }\end{array}$ \\
\hline
\end{tabular}




\subsection{Place Image: A Tourist District of Traditional Culture}

The current image of SLL is that of a place for tourism. Due to the demand for commercial land in the inner city of Beijing, the local government invested in the facilities of SLL. It allowed private investment in SLL, some of which came from abroad. Because most of the elites' former houses in SLL still belong to the government, the private investors cannot make profit through buying and selling elites' former houses. Moreover, those investors would have less interest in historical preservation than profit, so SLL would gradually lose its image as a historical district and thus its appeal to capital. The government has also invested very little money in repairing shabbier houses, so prosperous shops and stores for tourists are now juxtaposed alongside the poorer properties in SLL. SLL has become a lower-income class and migrant residential district. In the process, many residents who lived in SLL have been forced out by tourist developments. The remaining residents have no ability to improve the quality of their housing, which therefore continues to decline.

In 2006, the East District government hired experts and scholars to develop the "Planning of SLL Protection and Development (2006-2020)" initiative. In the plan, SLL is positioned as the heart of the metropolis, an example of a native Hutong, and a representation of authentic Beijing residential style [70]. Some scholars have argued that old and declining areas of cities often come to be seen as new economic assets [71].There are always important social impacts associated with such interventions [2] (p. 401). The case of SLL demonstrates this. Investment in SLL during the current period has totally changed from previous periods. Previous investments went into the houses that people were living in. Now, capital is only being invested in buildings that can be changed into shops and stores for tourists. For example, the No. 7 of Qiangulouyuan Hutong, which was the residence of the Guaracas family, Shoushan Song and Zhaoxiang $\mathrm{Wu}$, has been transformed into a dining and accommodation center named Qintangfu Courtyard 7. It is claimed that the new courtyard has received more than 50,000 guests since it opened in 2008, most of them from Germany and France [72]. Overall, the image of SLL had been transformed as it has become more integrated into the global tourism market.

The question of how to protect the historical legacy of SLL is a challenge faced by the local people and local government. There are two ways to respond this challenge. One is for the government to invest in residential houses that are on the back streets or back lanes. We know that private capital will not go to houses that do not generate profit for investors. Since 2012, the East District government has spent 10 million RMB a year repairing poor quality houses in SLL [73]. This will narrow the wealth gap between local residents and those who are involved in tourist businesses, even though the amount of money being spent is quite modest. A second strategy would be to create a new image for SLL, one that encourages people to take greater note of the historical courtyards. Processes of identification associated with place-making are always temporary, uncertain, and in process [38] (p. 190). "Place" must be understood as dynamic and fluid [74] and its identity is always in the process of becoming: it is, in a sense, never secured [38] (p. 186). There is no reason why a new image cannot emerge in place of the old image of SLL.

\section{Conclusions}

In this paper, we analyzed the transformation of SLL in central Beijing over the course of four historical periods. The logical relationship of the four periods is that capital flowed to where it could 
gain profit (see Figure 8). In the first period, the location of SLL attracted capital. In the second period, the capital went to where the previous investment had created a high quality built environment and good quality houses for rich people. In the third period, the private property regime was eclipsed by state ownership, and capital investment in SLL went into decline. In the fourth period, the government allowed private investment in real estate. The location of SLL and the density of elites' former houses attracted capital to this area again. Figure 8 shows the logical relationship among the four layers. It also shows that the image of SLL has changed from one period to the next. We can see that the succession of images has a core that comes from the elites' residential culture. In the fourth period, this culture is linked to the consumption practices of tourists.

We draw four main conclusions from our case study. First, the location of SSL has been the key factor that enabled it to become a prestigious residential community near the imperial city. Since the Yuan Dynasty, the center of Beijing has not changed. Thus, the location of SSL has not changed very much since then and it has retained its strategic location within the city.

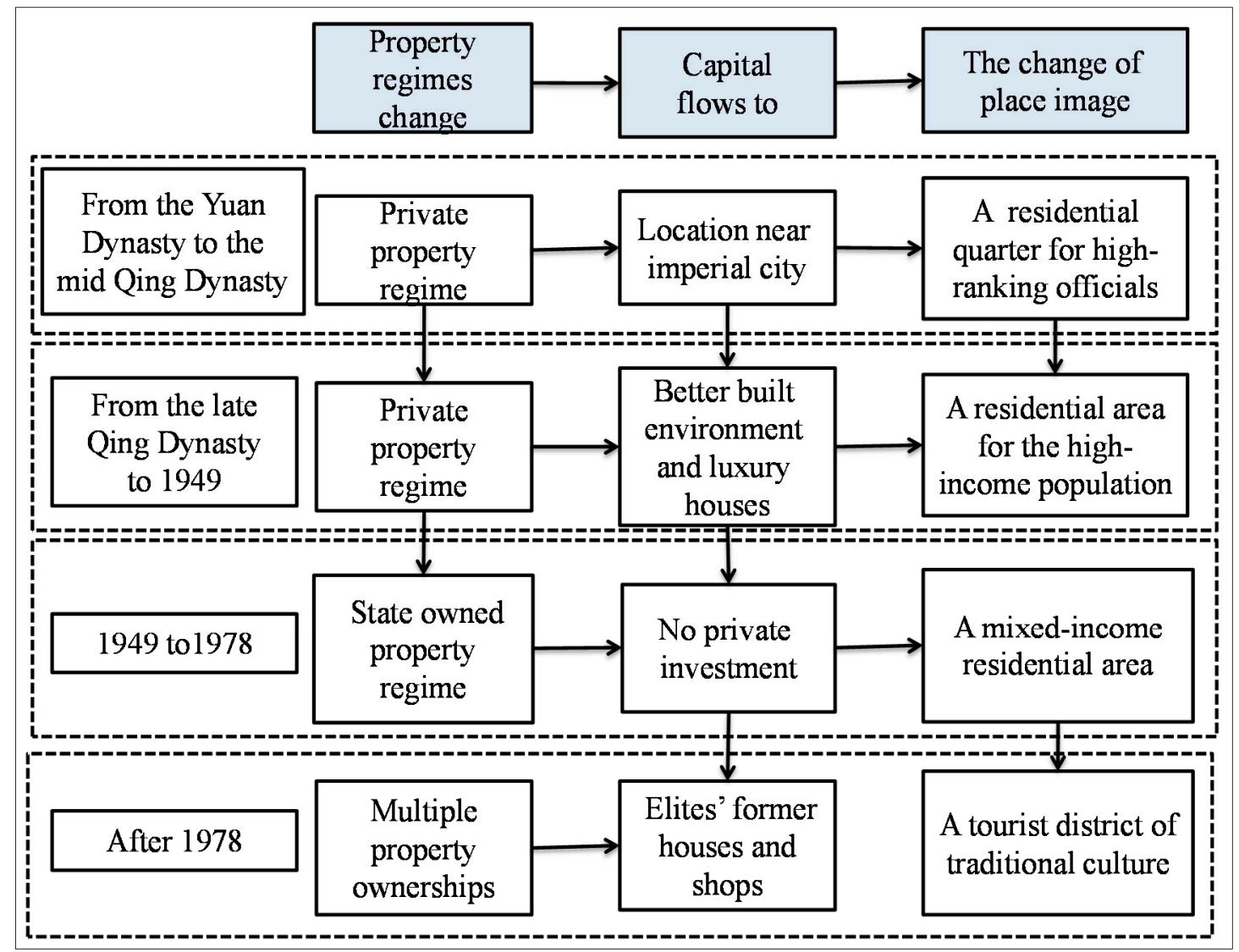

Figure 8. The paper's logic and the logical relationship among the layers.

Second, during the period of private property regimes, the purpose of elites who purchased houses was not only to live there; the houses were also an investment. Because of the unique location of SLL, investing in the houses could lead to a higher return in profit. The elites' former houses were the most attractive for investment. By comparing Figures 4 and 6, it can be seen that prior capital investment in houses in SSL by the political elites and military elites directly influenced subsequent capital flows into the same area. The surrounding areas or communities, which have a similarly strategic location, have a lower density of elites' houses. 
Third, during PRC and following the reforms of 1978, individuals could not make profit through buying and selling the houses due to changes in China's property regime. The houses gradually became run down. Government investment in the wider community has attracted commercial investment to SLL. Thus, the laws of land ownership and real estate property ownership can change the target area and intensity of capital flows to real estate.

Fourth, a change in capital flows leads to a change in the image of a place. The place image of SLL changed from a residential quarter for high-ranking officials in the first period to one for a higher-income population in the second period. In the third period, it was seen as a mixed-income residential area, whereas it is now considered to be a tourist district of traditional culture.

The objective of this paper has been to make links between changing property regimes and place-making in SLL.A change of property regimes led to a transformation in the fortunes of elites' former houses. It led to disinvestment in the houses, which accelerated under the redistributive property regime of socialist China. However, this has recently been reversed by an influx of global capital. However, these capital flows now target tourism. The local impacts of global tourism have created a number of challenges in SLL. These are not only economic or environmental issues but also social and cultural ones [75]. A number of challenges concern the question of how to preserve certain historical features as tourism continues to increase [76]. Maintaining the "local culture" of SLL has become an even more complex question.

\section{Acknowledgments}

This research is supported jointly by the Project of NSFC (No. 41271152, J1103403), the Project of Beijing Municipal Education Commission (SM201311417007), the Project of Beijing Social Science Fund (14JDCSC007). We are very grateful to Baoxiu Zhang from Beijing Union University for providing some elites' former houses data in Beijing. We acknowledge the help provided by Yan Tian, Xiaoqun Lin and Xiaofeng Liu from Beijing Normal University for some translations. We would like to thank Xiaofeng Liu for the help in the making of Figure3.

\section{Author Contributions}

Zhifen Cheng wrote the major parts of the paper, collected the original sources and data, and created the figures and tables. Shangyi Zhou contributed to the conceptual framework of the methodology and wrote some parts of the article. Stephen Young rewrote some parts of the paper and assisted with language and grammar issues.

\section{Conflicts of Interest}

The authors declare no conflict of interest.

\section{References and Notes}

1. Power, A. Social Exclusion and Urban Sprawl: Is the rescue of cities possible? Reg. Stud. 2001, 35, $731-742$. 
2. Razzu, G. Urban redevelopment, cultural heritage, poverty and redistribution: the case of Old Accra and Adawso House. Habitat Int. 2005, 29, 399-419.

3. Yeoh, B.; Kong, L. The notion of place in the construction of history, nostalgia and heritage in Singapore. Singap. J. Trop. Geogr. 1997, 17, 52-65.

4. Massey, D. A Global Sense of Place. In Space, Place, and Gender; University of Minnesota Press: St. Paul, MN, USA, 1994; pp. 146-157.

5. Harvey, D. The right to the city. Int. J. Urban Reg. Res. 2003, 27, 939-941.

6. Massey, D. For Space; Sage Publications Ltd.: London, UK, 2005; pp. 50-150.

7. McDowell, L.; Massey, D. A woman's place? In Geography Matters! A Reader; Massey, D., Allen, J., Eds.; Cambridge University Press: Cambridge, UK, 1984; pp. 128-147.

8. Warde, A. Spatial change, politics and the division of labour. In Social Relations and Spatial Structures; Gregory, D., Urry, J., Eds.; Macmillan: London, UK, 1985; Volume 25, pp. 198-199.

9. Gregory, D. Areal differentiation and post-modern human geography. In Horizons in Human Geography; Gregory, D., Walford, R., Eds.; Macmillan: London, UK, 1989; pp. 67-96.

10. Harver, D. Justice, Nature and the Geography of Difference; Blackwell: Oxford, UK, 1996; pp. 295-296.

11. Harvey, D. Social Justice and the City; The University of Georgia Press: Athens, Greece, 2009; pp. 62-66.

12. Harvey, D. Spaces of Hope; University of California Press: Berkeley, CA, USA, 2000; pp. 56-58.

13. Hudson, R. Producing Places; Guilford Press: New York, NY, USA, 2001; p. 256.

14. Hubbard, P., Kitchin, R., Valentine, G., Eds. Key Thinkers on Space and Place; Sage: London, UK, 2004; p. 6.

15. Pierce, J.; Martin, D.; Murphy, J. Relational Place-Making: the networked politics of place. Trans. Inst. Br. Geogr. 2011, 36, 54-70.

16. Massey, D. New directions in space.InSocial Relations and Spatial Structures; Gregory, D., Urry, J., Eds.; Macmillan: London, UK, 1985; Volume 25, pp. 9-19.

17. Massey, D. Spatial Divisions of Labor: Social Structures and the Geography of Production; Methuen: New York, NY, USA, 1984.

18. Warwick, M.; John, O. Defining Regions: the making of places in the New Zealand wine industry. Aust. Geogr. 2011, 42, 419-433.

19. Cresswell, T. Place: A Short Introduction; John Wiley \& Sons: Hoboken, NJ, USA, 2013; pp. 38-41.

20. Massey, D. Power-Geometry and a Progressive Sense of Place. In Mapping the Futures: Local Cultures Global Change; Bird, J., Curtis, B., Putnam, T., Tickner, L., Eds.; Routledge: London, UK, 1993; pp. 59-69.

21. Li, T.; Zhang, E. The History of SLL; Beijing Publishing House: Beijing, China, 2010; pp. 2-180. (In Chinese)

22. Xiong, M. Xi Jin Zhi Ji Yi, 2nd ed.; Beijing Ancient Books Publishing House: Beijing, China, 2001; p. 2. (In Chinese)

23. Lv, B. SLL in Jiaodaokou. Beijing Plan. Rev. 2007, 5, 139-142.

24. China National Tourism Administration classifies tourist places into 5 levels. Each level has A and B grade. 
25. Wang, L. Studies on China Urban Land Property Right; Social Sciences Academic Press: Beijing, China, 2006; pp. 17-100. (In Chinese)

26. Lin, X.; Zhang, H.; Chen, B.; Hu, J. The Housing Land Management in the East District in Beijing; Housing and Land Administration Bureau: Beijing, China, 1998; pp. 3-400. (In Chinese)

27. Zheng, J. Tian Zhi Ou Wen, 2nd ed.; Beijing Ancient Books Publishing House: Beijing, China, 1982; p. 85. (In Chinese)

28. The "Eight Bannermen" System was Set up by the Emperor in Qing Dynasty for His Political Goal. It Provided the Basic Framework for the Manchu Military Organization. The Eight Bannermen Were Plain Yellow Bannermen, Bordered Yellow Bannermen, Plain White Bannermen, Bordered White Bannermen, Plain Red Bannermen, Bordered Red Bannermen, Plain Blue Bannermen, Bordered Blue Bannermen. Then, Based on people's Culture and the Language (Not the Ancestry, Race or Blood), they were again Divided into Three Types of Main Bannermen, the Manchu Bannermen, Mongol Bannermen and Han Bannermen. The Bannermen had a Hierarchical Structure. Available online: http://en.wikipedia.org/wiki/Eight_Banners (accessed on 5 August 2014).

29. Dang, J. The Advice about the Protection of Elites' Former Houses in SLL. Available online: http://www.bj93.gov.cn/czyz/jyxc/t20130917_215917.htm (accessed on 17 September 2013). (In Chinese)

30. Yu, M. Ri Xia Jiu Wen Kao, 2nd ed.; Beijing Ancient Books Publishing House: Beijing, China, 2001; p. 578. (In Chinese)

31. Wu, C. Chen Yuan Shi Lue, 2nd ed.; Beijing Ancient Books Publishing House: Beijing, China, 2001; p. 109. (In Chinese)

32. Zhu, Y. Jing Shi Fang Xiang Zhi Gao, 2nd ed.; Beijing Ancient Books Publishing House: Beijing, China, 2001; p. 81. (In Chinese)

33. Zhao, L. Xiao Ting Za Lu; Zhong Hua Press: Beijing, China, 1980; p. 510. (In Chinese)

34. Dang, J. The historical and cultural relics in SLL. Beijing Arch. 2011, 5, 52-53. (In Chinese)

35. Jia, Q. Wen Yu's garden. Trad. Chin. Archit. Gard. 2000, 1, 52-54.

36. Anonymous. SLL. Econ. Trade Update 2011, 8, 9-11.

37. Beijing Municipal Government, China. The Letter and List, Draw Money Duplicate, etc. from the No. 4 Municipal Administration in Beijing and They Were the Approval of Repairing the Road, the Gap with Lid from Mianhua Hutong to the South of SLL; Beijing Archives Administration: Beijing, China, 1919; J017-001-00109. (In Chinese)

38. Massey, D. Places and Their Pasts. Hist. Workshop J. 1995, 39, 182-192.

39. Massey, D. Spatial Divisions of Labor: Social Structures and the Geography of Production, 2nd ed.; The Macmillan Press Ltd.: Hampshire, UK, 1995; pp. 17-28.

40. Shan, J. Conservation Planning of 25 Historic Areas in Beijing Old City; Beijing Yanshan Publishing House: Beijing, China, 2002; pp. 155-168. (In Chinese)

41. Zhang, Q. The confusion and digestion of the urban land under the background of "All belong to the country". China Leg. Sci. 2012, 3, 178-190.

42. Cai, J. The 60 years of land system reform in new China: A review and prospect. China Nat. Cond. Strength. 2009, 9, 4-7.

43. Wu, C.; Jin, X. Thirty Years of Land System Reform in China; The Science Press: Beijing, China, 2009; pp. 10-78. (In Chinese) 
44. Zhang, X. Urban land reform in China. Land Use Policy 1997, 14, 187-199.

45. Li, J.; Dai, S. The retrospect and prospect of Chinese city land use system reform in 60 years. Rev. Econ. Res. 2009, 63, 2-10.

46. Li, Y. The historical changes and countermeasures of Chinese urban housing system. Acad. J. Zhongzhou 2007, 3, 134-136.

47. Chen, J. Qinlao Hutong (2): Qinlao Hutong in SLL. Available online: http://blog.sina.com.cn/ $\mathrm{u} / 1253711215$ (accessed on 26 September 2012). (In Chinese)

48. The Editorial Department of Beijing Volume. Books of Contemporary Chinese City Development; Contemporary China Press: Beijing, China, 2011; pp. 46-60. (In Chinese)

49. Zhang, Z. Research on the Reform of the Land System in The Process of Urbanization; Hebei People's Press: Shijiazhuang, China, 2013; pp. 143-151. (In Chinese)

50. $\mathrm{Hu}, \mathrm{W}$. The Research on Efficiency and Justice Land System Reform of China. Ph.D. Thesis, University of Geosciences, Beijing, China, 2012; pp. 16-17. (In Chinese)

51. Liu, J. The changes of land system in China and its problems. Friends Farmers Get Rich. 2011, 13, 68.

52. Jin, J. The reform and development of Beijing land use system in the 60 years after the new Chinese founded. Beijing Plan. Rev. 2009, 6, 15-20.

53. Song, X. Research of the Case of Transformation and Renewal of the South Lane Area in Beijing. Master's Thesis, Beijing University of Civil Engineering and Architecture, Beijing, China, 2010; pp. 97-106. (In Chinese)

54. Liu, X., Ed. Beijing East District Yearbook-1996; The Olympic Press: Beijing, China, 1997; pp. 245-247. (In Chinese)

55. Liu, X., Ed. Beijing East District Yearbook—1997; The Olympic Press: Beijing, China, 1998; pp. 277-279. (In Chinese)

56. Liu, X., Ed. Beijing East District Yearbook-1998; The Olympic Press: Beijing, China, 1999; pp. 264-265. (In Chinese)

57. Liu, X., Ed. Beijing East District Yearbook—1999; The Olympic Press: Beijing, China, 2000; pp. 320-323. (In Chinese)

58. Chen, P., Ed. Beijing East District Yearbook—2000; People's Publishing House: Beijing, China, 2002; pp. 298-300. (In Chinese)

59. Chen, P., Ed. Beijing East District Yearbook -2001; Tongxin Press: Beijing, China, 2002; pp. 314-317. (In Chinese)

60. Lu, Y., Ed. Beijing East. District Yearbook-2003; National Publishing House: Beijing, China, 2003; pp. 312-315. (In Chinese)

61. Lu, Y., Ed. Beijing East. District Yearbook-2004; National Publishing House: Beijing, China, 2004; pp. 315-318. (In Chinese)

62. Lu, Y., Ed. Beijing East District Yearbook-2006; Local Records Press: Beijing, China, 2006; pp. 297-300. (In Chinese)

63. Yang, Y., Ed. Beijing East District Yearbook-2007; Local Records Press: Beijing, China, 2007; pp. 319-323. (In Chinese)

64. Yang, Y., Ed. Beijing East District Yearbook-2008; Local Records Press: Beijing, China, 2008; pp. 284-288. (In Chinese) 
65. Yang, Y., Ed. Beijing East District Yearbook-2009; Local Records Press: Beijing, China, 2009; pp. 361-366. (In Chinese)

66. Niu, Q., Ed. Beijing East District Yearbook-2010; The Central Literature Publishing House: Beijing, China, 2010; pp. 328-334. (In Chinese)

67. Niu, Q., Ed. Beijing East District Yearbook-2011; Zhong Hua Press: Beijing, China, 2012; pp. 339-340. (In Chinese)

68. Zhang, R. This Characteristics Street SLL's Expansion This Year. Jinghua Times, 16 January 2010, p. 7. (In Chinese)

69. Niu, Q., Ed. Beijing East District Yearbook-2012; Zhong Hua Press: Beijing, China, 2012; pp. 305-306. (In Chinese)

70. Huang, B.; Dai, L.; Hu, Y.; Lv, B. A study on the influence mechanism of cultural and creative industries in the old city regeneration from the space production perspective-Taking SLL as a case. Beijing Plan. Rev. 2012, 3, 106-111.

71. Rojas, E. Old Cities, New Assets: Preserving Latin America's Urban Heritage; The Johns Hopkins University Press: Baltimore, MD, USA, 1999.

72. Min, Z. Yard Deep Memories of Ancient Culture. Beijing Daily, 23 March 2012, p. 12. (In Chinese)

73. Li, M. Poor Families in Beijing can Apply Fund from Local Government for House Repair. Available online: http://news.xinhuanet.com/politics/2014-06/11/c_1111079550.htm (accessed on 11 June 2014). (In Chinese)

74. Adams, P.C., Hoelscher, S.D., Till, K.E., Eds. Textures of Place: Exploring Humanist Geographies; University of Minnesota Press: St. Paul, MN, USA, 2001; p. xxxi.

75. Jamal, T.; Stronza, A. Collaboration theory and tourism practice in protected areas: Stakeholders, structuring and sustainability. J. Sustain. Tour. 2009, 17, 169-189.

76. Eagles, P. Global trends affecting tourism in protected areas. In Tourism in Protected Areas: Benefits beyond Boundaries; Bushell, R., Eagles, P., Eds.; CAB International: Wallingford, UK, 2007: pp. 27-43.

(C) 2014 by the authors; licensee MDPI, Basel, Switzerland. This article is an open access article distributed under the terms and conditions of the Creative Commons Attribution license (http://creativecommons.org/licenses/by/4.0/). 